\title{
The threat of allergenic airborne trees pollen to pollinosis sufferers in a rural area (Western Pomerania, Poland)
}

\author{
Aleksandra Kruczek ${ }^{1,2 *}$, Małgorzata Puc ${ }^{1,2}$, Alina Stacewicz ${ }^{1,2}$, Tomasz Wolski ${ }^{3}$ \\ 1 Department of Botany and Nature Conservation, Faculty of Biology, University of Szczecin, Felczaka 3c, 71-412 Szczecin, Poland \\ ${ }^{2}$ Molecular Biology and Biotechnology Center, Faculty of Biology, University of Szczecin, Wąska 13, 71-415 Szczecin, Poland \\ ${ }^{3}$ Department of Geosciences, Institute of Marine and Coastal Sciences, University of Szczecin, Mickiewicza 16, 70-383 Szczecin, Poland
}

\begin{abstract}
The aim of the study was to investigate the concentration of Alnus L., Corylus L. and Betula L. pollen in the village of Gudowo (Western Pomerania, Poland) in the years 2012-2014 in order to estimate the threat of allergenic tree pollen in this rural region. Measurements were performed using the volumetric method (VPPS Lanzoni 2000 pollen sampler). The duration of the pollen season was determined by the $98 \%$ method, taking days on which, respectively, $1 \%$ and $99 \%$ of the annual total pollen grains appeared as the beginning and end of the season. Pollen grains from hazel occurred in the air as the first ones, before pollen grains from alder and birch. The earliest beginning of the hazel pollen season was recorded in 2012, whereas alder and birch pollen seasons started the earliest in 2014. Daily maximum pollen concentrations of the investigated taxa were recorded in 2014. Birch pollen allergens posed the largest threat to pollinosis sufferers. In the years 2012-2014, pollen concentrations equal or higher than threshold values, at which people with pollinosis show allergic symptoms, were recorded most frequently for birch, hazel, and alder (25,19, and 14 days, respectively). The highest hourly alder pollen concentration was recorded at 16:00 and in the case of hazel at 15:00. The diurnal distribution of birch pollen concentrations does not show any distinct peaks.
\end{abstract}

Keywords: aerobiology; allergy; alder; hazel; birch

\section{Introduction}

Allergy is an abnormal response of a hypersensitive organism to various surrounding environmental factors (allergens), which are harmless to sensitive people [1]. Allergic rhinitis is a common disease in many countries. Approximately $10-30 \%$ of the general population suffer from it [2]. The symptoms of allergic rhinitis include nasal itching, sneezing, rhinorrhoea, and a feeling of nasal congestion [3]. Pollen allergens, house dust mites, and animal epidermal allergens contribute to allergic rhinitis [4].

The seasonal character of the symptoms is a distinctive feature of allergic diseases evoked by pollen allergens. The severity of symptoms in pollinosis sufferers is closely linked to the concentration of allergens in the atmosphere. Intensification of disease symptoms grows simultaneously with the increase of the pollen concentration in the atmosphere [5].

The most common cause of the allergic disease symptoms is pollen of anemophilous trees and shrubs, especially species that flower before development of leaves, which makes

\footnotetext{
*Corresponding author. Email: aleksandra.kruczek@univ.szczecin.pl
}

Handling Editor: Agnieszka Grinn-Gofroń it easier for pollen grains to spread. What is more, some trees and shrubs show periodicity of flowering. They cannot flower intensely every year, but only in seminal years. Flowering and pollination are features of given plant species and, therefore, observation of their blooming and pollination is essential [1]. In terms of allergenicity and the causes of allergic disease, hazel, alder, and birch pollen allergens are clinically most distinctive [6].

Hazel is a monoecious, high tree or shrub with wide heart-shaped leaves. It flowers from January to April, before leaves develop. The flowering of hazel marks the beginning of botanical early spring. Male flowers are collected in drooping, cylindrical catkins, which are formed in late autumn [7]. At the time of flowering, the axis of inflorescence lengthens, thereby ensuring looser flower arrangement and facilitating removal of pollen from the anther by the wind [8]. Female flowers are gathered in groups of a few and are covered by brown shells, from which only red pistil stigmas lean forward during flowering [7]. In Poland, only Corylus avellana occurs in its natural habitat and it is common in forests and clearings in the whole country, including the lower montane forest zone [9]. The first disease symptoms of allergy to hazel pollen appear at a concentration of 35 pollen grains in $1 \mathrm{~m}^{3}$ of air [3]. Allergy to hazel pollen allergens often coincide with 
allergy to birch and alder pollen allergens as well as hazelnut alimentary allergens. Because of the cross-reactivity between pollen grains of the Betulaceae family, hazel pollen allergens play a considerable role in allergology [10].

Alder is a monoecious tree or shrub with elliptic or ovate, double-serrated leaves. It flowers from February to April. Male flowers are gathered in catkins, formed in late summer, and after winter unfold before leaves developed. The female inflorescence has a shape of small cones [7]. Alnus incana (L.) Moench, Alnus glutinosa (L.) Gaertn., and Alnus viridis (Chaix) DC. in Lam. \& DC are widely distributed in Poland. Flowers of $A$. incana develop 2-3 weeks earlier than in $A$. glutinosa, whereas $A$. viridis flowers are the last to develop [11]. The first disease symptoms of allergy to alder pollen occur at a concentration of 45 pollen grains in $1 \mathrm{~m}^{3}$ of air [3]. Alder pollen allergens trigger cross-reactions with the pollen allergens of hazel and birch and alimentary allergens of apple, peach, and hazelnuts [11]. Alder pollen allergens have high clinical importance as they are responsible for early-spring allergic rhinitis and conjunctivitis [12,13].

Birch is a monoecious tree with single, ovate, serrated leaves, frequently planted because of the decorative value of its whitish bark. Male flowers are gathered in yellowish green, dangling, cylindrical catkins. Birch flowers from April to May, concurrently with development of its leaves. In Poland, 7 species of Betula occur in its natural habitats. The most common are Betula pendula Roth, typical for dry and sandy areas, and Betula pubescens Ehrh., preferring damp, swampy, and peat sites [7]. The first allergic symptoms to birch pollen occur at a concentration of 20 pollen grains in $1 \mathrm{~m}^{3}$ of air [3]. Birch pollen allergens trigger cross-reactions with pollen allergens of alder, hazel, hornbeam, oak, beech, apple-tree, and walnut-tree [14]. The birch pollen concentration reaches high levels, often causing severe allergic reactions, including asthmatic reactions. The allergens of birch are among the most common causes of allergic respiratory diseases in our climate zone. In strongly hypersensitive people, allergic symptoms appear after contact with birch pollen grains that are spread in house dust [15].

The aim of the study was to present the concentration of Alnus L., Corylus L., and Betula L. pollen in the rural area (village of Gudowo, Western Pomerania, Poland) in the years 2012-2014.

\section{Material and methods}

The aerobiological monitoring was conducted with the volumetric method (VPPS Lanzoni 2000) in the village of Gudowo (Western Pomerania, Poland) in the years 2012-2014. Gudowo (500 inhabitants) lies on Lubie Lake. The village landscape is dominated by houses with adjoining farm buildings, fields, and grasslands. There are also numerous woodlots and forests. The pollen trap $\left(53^{\circ} 29^{\prime} 34^{\prime \prime} \mathrm{N}\right.$, $15^{\circ} 51^{\prime} 44^{\prime \prime} \mathrm{E}$ ) was mounted on the roof at a level of approx. 3.5 $\mathrm{m}$ above the ground. The trap is recommended by the IAA (International Association for Aerobiology). The instrument takes samples of air in a volume corresponding to the average human respiratory parameters. The samples were examined with the use of a light microscope at $400 \times$ magnification. Pollen grains were counted along 4 longitudinal transects (a method that is recommended by the Spanish aerobiological network (REA) [16]. The results are given as the number of pollen grains in $1 \mathrm{~m}^{3}$ of air per 24 hours. Based on the results, a pollen calendar for Gudowo (Fig. 1) was prepared.

The course of the pollen seasons is presented in Fig. 2. The duration of the pollen season was determined by the $98 \%$ method [17]. The SPI index, which is a sum of daily pollen counts in a season, was fixed in order to compare the abundance of pollen seasons of the investigated taxa [18]. According to the literature data, the number of days in which the pollen count exceeds the threshold required for the onset of symptoms in patients with allergy was fixed. The diurnal patterns of hazel, alder, and birch pollen concentration on days in which the pollen count exceeded the threshold concentration were examined. In order to compare the dynamics of seasons [19], consecutive phases of the pollen seasons were determined: 1 - onset of the season, corresponding to $1 \%$ of the annual pollen total, 2 - 2.5-5\%, 3 - 5-25\%, 4 - 25-50\%, 5 - 50\%, 6 - 50-75\%, $7-75-95 \%, 8-95-97.5 \%$, and 9 - end of the season, corresponding to $99 \%$ of the annual pollen total. The influence of weather parameters on the pollen count of hazel, alder, and birch in the air were examined with Spearman's rank correlation coefficients. The weather data were obtained from the meteorological station in Drawsko Pomorskie (5 $\mathrm{km}$ from Gudowo).

\section{Results}

The pollen calendar for Gudowo was prepared on the basis of the results obtained (Fig. 1). Hazel pollen grains appeared first in the air, before alder and birch pollen. In 2012, the hazel pollen season started 50 days earlier than in 2013 and 31 days earlier than in 2014. Hazel pollen floated in the air for 45 days on average. The pollen season was most abundant in 2013. In 2014, the alder pollen season started 21

\begin{tabular}{|c|c|c|c|c|c|c|}
\hline Taxon & I & II & III & IV & V & VI \\
\hline Alnus & & & & & & \\
\hline Corylus & & & & & & \\
\hline Betula & & & & & & \\
\hline
\end{tabular}

Fig. 1 Pollen calendar for Gudowo (100\% SPI), 2012-2014. Scale according to Hofman and Michalik [1], changed. The concentration of pollen in the air $\left(\mathrm{p} / \mathrm{m}^{3} / 24 \mathrm{~h}\right)$ : white - absence of pollen in the air; azure - single grains (1-5); blue - very low (6-10); dark blue - low (11-20); navy blue - medium (21-50); orange - high (51-100); maroon - very high $(>100)$. 


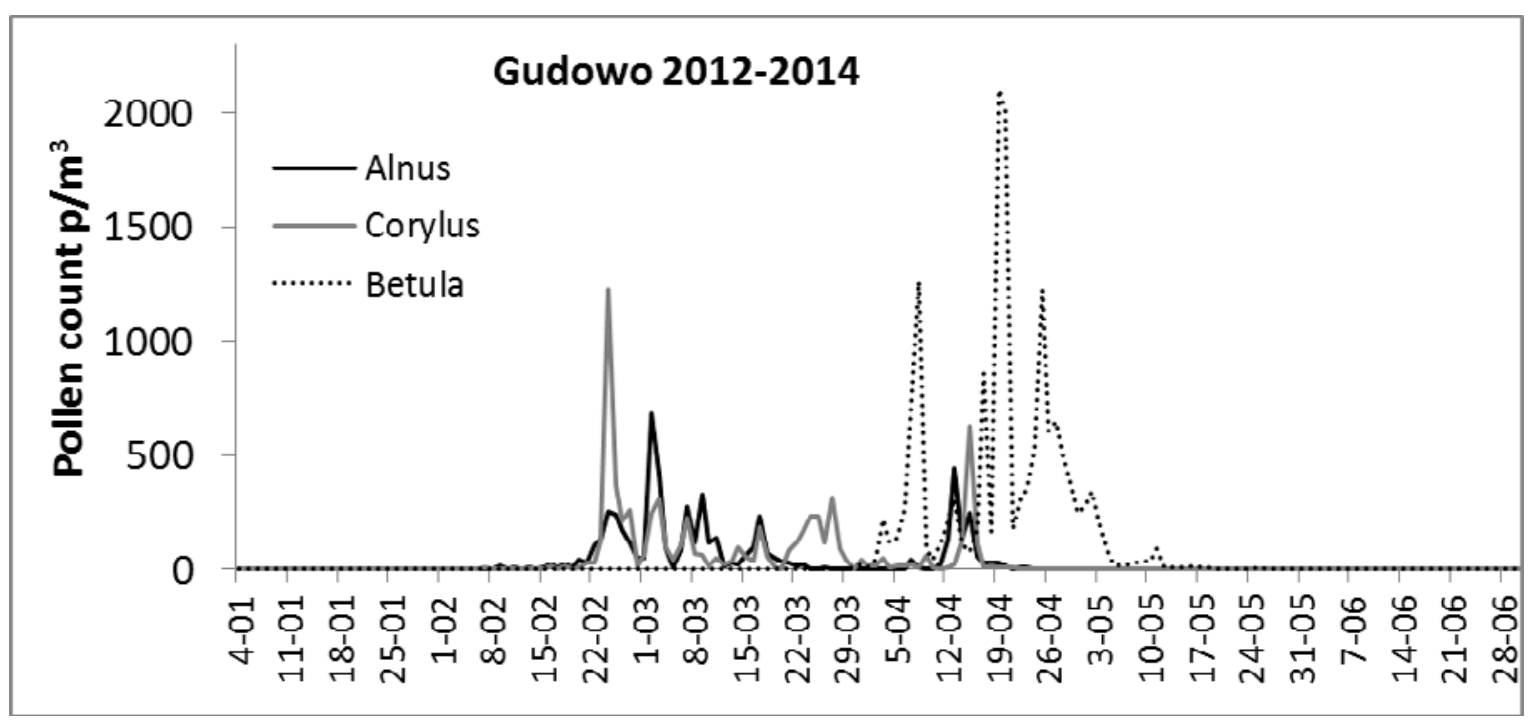

Fig. 2 The mean course of pollen seasons of Alnus L., Corylus L. and Betula L. in Gudowo in the years 2012-2014.

days earlier than in 2012 and 15 days earlier than in 2013. It lasted 39 days longer on average. The pollen season was most abundant in 2014. In 2014, the birch pollen season started 7 days earlier than in 2012 and 19 days earlier than in 2013. It was the shortest, i.e. 29 days. The pollen season was most abundant in 2014. The highest values of maximum concentrations of investigated taxa were noticed in 2014 (Tab. 1).

In the years 2012-2014, pollen counts equal or higher than the threshold values were noticed for 25 days on average in the case of birch, for 19 days in the case of hazel, and for 14 days in the case of alder. The threat of alder and birch pollen allergens was the greatest in 2014, whereas hazel posed the highest risk in 2013 (Tab. 2). The percentage of birch pollen in relation to the annual total concentration of the pollen of the investigated taxa was the highest $-55.57 \%$. The percentage of hazel pollen was $24.5 \%$. In turn, the lowest percentage (20\%) was noticed in the case of alder pollen grains.
The pollen seasons of Alnus L. and Corylus L. were characterized by year-to-year variation periods of an increasing and decreasing pollen count (Fig. 2). The birch pollen season was short and intensive, in contrast to the alder and hazel pollen seasons, in which pollen grains persisted in the air for the longest time. The average daily pollen concentration and SPI in the case of alder and hazel were lower than those of birch pollen.

In the hazel and alder pollen seasons, phase 3 lasted for the longest period (Fig. 3). Phase 3 is a period in which a $5-25 \%$ SPI in the air is noted. In the case of birch, all phases lasted similarly long.

During the daytime, alder and hazel pollen counts achieved a clearly maximum value in the afternoon. The highest alder pollen concentration was noticed at 16:00 and in the case of hazel at 15:00 (Fig. 4). The diurnal pattern of birch pollen counts did not show distinctive peaks. The

Tab. 1 Characteristics of the pollen seasons of Alnus L., Corylus L. and Betula L. in Gudowo in the years 2012-2014.

\begin{tabular}{|c|c|c|c|c|c|c|c|c|}
\hline \multirow[b]{2}{*}{ Taxon } & \multirow[b]{2}{*}{ Year } & \multicolumn{3}{|c|}{ Pollen season } & \multirow[b]{2}{*}{$\begin{array}{l}\text { Maximum value } \\
\left(\text { pollen } / \mathbf{m}^{3}\right)\end{array}$} & \multirow[b]{2}{*}{$\begin{array}{l}\text { Date of the } \\
\text { max. value }\end{array}$} & \multirow{2}{*}{$\begin{array}{c}\text { The highest } \\
\text { monthly } \\
\text { concentrations }\end{array}$} & \multirow[b]{2}{*}{ SPI } \\
\hline & & start & end & $\begin{array}{l}\text { duration } \\
\text { (days) }\end{array}$ & & & & \\
\hline \multirow[t]{3}{*}{ Alnus } & 2012 & $6 \mathrm{III}$ & $5 \mathrm{IV}$ & 31 & 664 & $16 \mathrm{III}$ & March & 1862 \\
\hline & 2013 & $1 \mathrm{III}$ & $23 \mathrm{IV}$ & 54 & 1333 & $13 \mathrm{IV}$ & April & 3851 \\
\hline & 2014 & 13 II & $15 \mathrm{III}$ & 31 & 2011 & 2 III & March & 10647 \\
\hline \multirow[t]{3}{*}{ Corylus } & 2012 & $14 \mathrm{I}$ & 19 III & 66 & 209 & 3 III & March & 819 \\
\hline & 2013 & $6 \mathrm{III}$ & $18 \mathrm{IV}$ & 44 & 1886 & $15 \mathrm{IV}$ & March & 9881 \\
\hline & 2014 & 16 II & $11 \mathrm{III}$ & 24 & 3664 & 24 II & February & 9407 \\
\hline \multirow[t]{3}{*}{ Betula } & 2012 & $10 \mathrm{IV}$ & $15 \mathrm{~V}$ & 36 & 1876 & $24 \mathrm{IV}$ & April & 9940 \\
\hline & 2013 & $23 \mathrm{IV}$ & $14 \mathrm{~V}$ & 22 & 751 & $26 \mathrm{IV}$ & May & 4069 \\
\hline & 2014 & $3 \mathrm{IV}$ & $1 \mathrm{~V}$ & 29 & 6209 & $19 \mathrm{IV}$ & April & 31607 \\
\hline
\end{tabular}


Tab. 2 The threat of Alnus L., Corylus L. and Betula L. allergenic pollen to pollinosis sufferers in Gudowo in the years 2012-2014.

\begin{tabular}{|c|c|c|c|c|c|}
\hline \multirow[b]{2}{*}{ Taxon } & \multirow[b]{2}{*}{ Year } & \multicolumn{4}{|c|}{$\begin{array}{l}\text { Days with overflow of pollen concentration which is connected to } \\
\text { clinical symptoms* }\end{array}$} \\
\hline & & first symptoms & $\begin{array}{l}\text { symptoms } \\
\text { present in all } \\
\text { patients }\end{array}$ & acute symptoms & $\begin{array}{l}\text { dyspnea } \\
\text { symptoms }\end{array}$ \\
\hline \multirow[t]{3}{*}{ Alnus } & 2012 & 8 & 6 & 6 & 0 \\
\hline & 2013 & 10 & 7 & 6 & 1 \\
\hline & 2014 & 24 & 19 & 19 & 2 \\
\hline \multirow[t]{3}{*}{ Corylus } & 2012 & 6 & 2 & 1 & N/A \\
\hline & 2013 & 33 & 23 & 16 & N/A \\
\hline & 2014 & 18 & 14 & 9 & N/A \\
\hline \multirow[t]{3}{*}{ Betula } & 2012 & 22 & 18 & 15 & 14 \\
\hline & 2013 & 18 & 14 & 14 & 8 \\
\hline & 2014 & 34 & 28 & 28 & 24 \\
\hline
\end{tabular}

* According to Rapiejko et al. [3].
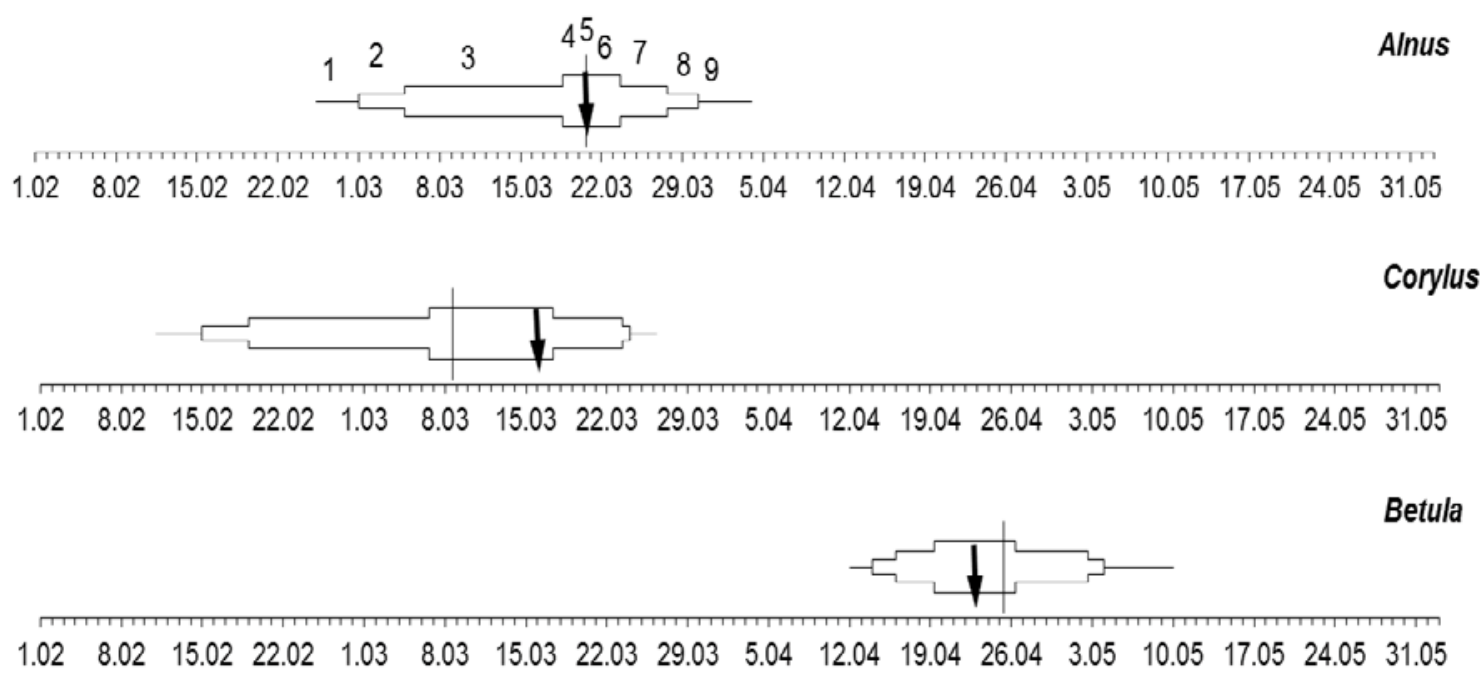

Fig. 3 The dynamics of pollen seasons of Alnus L., Corylus L. and Betula L.; the phase of seasons: 1 - the beginning of the season for $1 \%$ of the annual total pollen; $2-2.5-5 \% ; 3-5-25 \% ; 4-25-50 \% ; 5-50 \%$ (vertical line); $6-50-75 \%$; 7 - 75-95\%; 8 - 95-97.5\%; 9 - the end of the season for $99 \%$ of the annual total pollen. Black arrow - date of maximum concentration of pollen in the season.

maximum birch pollen count was noticed at 10:00. The hourly distribution of birch pollen count is skewed to the left, whereas that of alder and hazel to the right.

Spearman's correlation coefficients showed that the alder and hazel pollen counts decreased, whereas the birch pollen count increased simultaneously with the increasing minimum, average, and maximum temperature, and with the increasing dew point temperature (Tab. 3). Additionally, a statistically significant negative correlation between the birch pollen count $(r=-0.10)$ and a positive correlation between alder $(r=0.09)$ and hazel pollen count $(r=0.15)$ and the average pressure were observed.

\section{Discussion}

In prophylaxis and treatment of allergic disease to pollen (pollinosis), pollen calendars prepared for specific areas are a valuable source of information. Measured at a point, the air pollen count is a result of many factors affecting the 


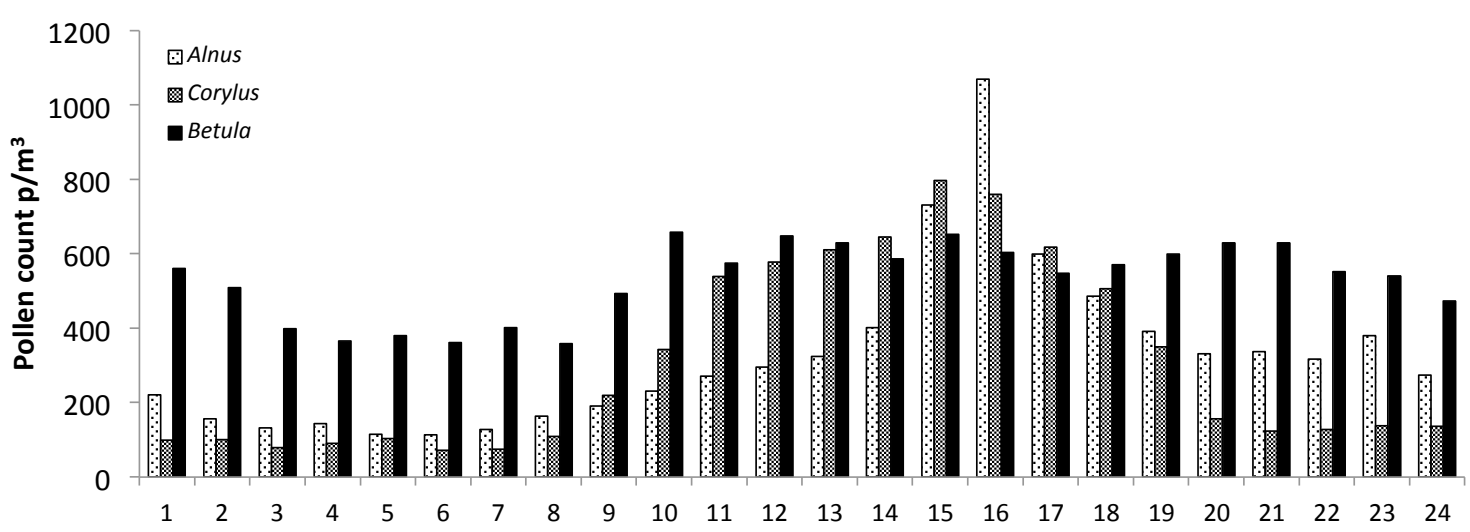

Fig. 4 Diurnal pattern of Alnus L., Corylus L. and Betula L. pollen counts.

production and dispersion of pollen in the atmosphere [20]. In view of the diversity of flora/vegetation and climatic conditions, a pollen calendar has a special value only for a specific area [21]. Therefore, the pollen calendar for Gudowo was prepared.

The knowledge of the onset of the allergenic plant pollen season and the variability of daily counts is very important for treatment planning [22]. Pollen seasons of different plant species vary in severity and the time of the beginning and end of pollination $[23,24]$. In our climate zone, spring (when trees pollinate) is characterized by extreme changes in weather conditions and major temperature fluctuations. These factors influence the date and intensity of tree pollen seasons [25]. In 2012, pollination of hazel started very early, in the first

Tab. 3 Spearman's rank correlation coefficients between mean daily pollen level and selected meteorological parameters.

\begin{tabular}{llccc}
\hline & & Alnus & Corylus & Betula \\
\hline Temp. $\left({ }^{\circ} \mathrm{C}\right)$ & max. & ${ }^{*}-0.15$ & ${ }^{*}-0.40$ & ${ }^{*} 0.43$ \\
& average & ${ }^{*}-0.22$ & ${ }^{*}-0.46$ & ${ }^{*} 0.41$ \\
& min. & ${ }^{*}-0.27$ & ${ }^{*}-0.45$ & ${ }^{*} 0.31$ \\
Dew point $\left({ }^{\circ} \mathrm{C}\right)$ & max. & ${ }^{*}-0.26$ & ${ }^{*}-0.47$ & ${ }^{*} 0.34$ \\
& average & ${ }^{*}-0.28$ & ${ }^{*}-0.47$ & ${ }^{*} 0.32$ \\
& min. & ${ }^{*}-0.30$ & ${ }^{*}-0.46$ & ${ }^{*} 0.28$ \\
Humidity $(\%)$ & max. & ${ }^{*}-0.12$ & ${ }^{*}-0.09$ & -0.08 \\
& average & -0.08 & ${ }^{*} 0.09$ & ${ }^{*}-0.42$ \\
Pressure $(\mathrm{hPa})$ & min. & ${ }^{*}-0.12$ & 0.08 & ${ }^{*}-0.43$ \\
& max. & ${ }^{*} 0.11$ & ${ }^{*} 0.18$ & ${ }^{*}-0.10$ \\
& min. & ${ }^{*} 0.09$ & ${ }^{*} 0.15$ & ${ }^{*}-0.10$ \\
Wind $(\mathrm{km} / \mathrm{h})$ & max. & 0.07 & ${ }^{*} 0.13$ & -0.07 \\
& average & 0.00 & 0.01 & 0.08 \\
& gust & -0.01 & -0.05 & 0.07 \\
\hline Precipitation $(\mathrm{cm})$ & sum & ${ }^{*}-0.12$ & -0.06 & -0.07 \\
\hline
\end{tabular}

* Statistical significance $P<0.05$. half of January, however later on, together with cooling and snowfall, pollination was substantially restricted. Hazel pollen was observed in the air only after withdrawal of frost. In next years, hazel pollen seasons started in the second half of February and at the beginning of March. The onset of hazel pollen season depends mainly on air temperature recorded at the turn of winter and spring [26]. Similar relationships were also observed by Weryszko-Chmielewska et al. [12], Puc and Kasprzyk [27], and Puc et al. [26]. Similar variation in the course of the alder pollen season was noticed by Rapiejko et al. [28] and Puc and Kasprzyk [27]. In the case of alder, the beginning and peak of the pollination period showed distinctive variation. In the individual years, depending on meteorological conditions, mainly temperature, the alder pollen season was subjected to fluctuations of up to 30-45 days. Also, a significant difference in the maximum values of alder pollen counts in the air were observed [25]. Similar variation regarding the beginning and time of duration of the pollen season, maximum values, and seasonal abundance in the individual years is shown in the present work.

The onset of birch pollination is usually abrupt with very high pollen counts and the process persists until the middle of April [29,30]. Similar results for the 3-year period were obtained for Gudowo. In the individual years, significant differences in the maximum birch pollen count values in the air and SPI values were noted. Year-to-year variation was also observed by Rapiejko et al. [29], and variation of the SPI in alder was observed by Lipiec and Rapiejko [31], Grewling et al. [32], and Myszkowska [30]. Pollination is affected by the geographical location and local climate [20]. The phases and duration of pollen seasons as well as annual totals of pollen grains depend heavily on the geographical position [33].

The number of pollen grains produced by a plant depends on conditions in the period when sporogenous tissue starts to develop in anthers (one year before pollination), whereas the intensity of pollination is affected by weather conditions directly before and at the pollination time [26,34]. Flowering and pollination are characterized by distinct periodicity connected with (among others) meteorological factors [26], and analogical results were obtained in the present work.

According to the types of pollen occurring in the air distinguished by Hyde [35], the birch pollen season belongs 
to the compact type, whereas the alder and hazel pollen seasons represent the diffused type. Kasprzyk [36] also includes the pollen seasons of Fraxinus, Carpinus, and Quercus in the compact type. Puc [37] includes Salix and Taxaceae/Cupresaceae in the diffused type. The compact type is characterized by taxa with a short and intensive flowering period. The diffused season is characterized by long presence of pollen in the air, often with many breaks and low intensity. It is characteristic for taxa in genus status with many species, in particular taxa flowering on different dates, with partially overlapping atmospheric pollen seasons [38]. During the alder and hazel pollen seasons in Gudowo, there were days when the pollen grains were not present in the air.

The value of the pollen count in the air is changing with hours of the day and night. This is connected with the time of anther opening, which is characteristic of individual plant taxa and, to a lesser extent, with air temperature rising within 24 hours [39]. In Gudowo, the highest alder pollen concentration was noticed at 16:00 and in the case of hazel at 15:00. Kasprzyk [40] claims that the pollination peak of these taxa occurs in the afternoon, i.e., that of alder at 15:00 and hazel at 17:00; additionally, he notices presence of another pollination peak of hazel early in the morning. Grewling et al. [41] observed an average diurnal hazel pollen concentrations peak around 14:00-16:00.

Direct effects of the influence of weather elements on the dynamics of spreading of bioaerosol are investigated by determination of a correlation between daily meteorological data values and daily values of the pollen count in the air [42]. In the present paper, maximum, average and minimum temperature, dew point temperature, and pressure are the

\section{Acknowledgments}

This study was financed from authors' private funds.

\section{Authors' contributions}

The following declarations about authors' contributions to the research have been made: conducting experiments, writing the manuscript: AK; research designing: MP; conducting experiments: AS; meteorological data: TW.

\section{Competing interests}

No competing interests have been declared.

\section{References}

1. Hofman T, Michalik J. Alergia Pyłkowa. Poznań: TotalDruk; 1998.

2. Cauwenberge P, Bacher C, Passalacqua G, Bousque J, Canonica GW, Durham SR, et al. Consensus statement on the treatment of allergic rhinitis. Allergy. 2000;55:116-134. http://dx.doi. org/10.1034/j.1398-9995.2000.00526.x

3. Rapiejko P, Lipiec A, Wojdas A, Jurkiewicz D. Treshold pollen concentration necessary to evoke allergic symptoms. International Review of Allergology and Clinical Immunology. 2004;10(3):91-94.

4. Rapiejko P. Aerobiologia medyczna. Alergia Astma Immunologia. 2006;11(2):76-82.

5. Rapiejko P. Pyłek roślin jako źródło alergenów. Przegląd Alergologiczny. 2004;1(1):7-12

6. Silny W, Czarnecka-Operacz M. Alergeny powietrznopochodne. Przewodnik Lekarza. 2001;4(3):112-117.

7. Seneta W, Dolatowski J. Dendrologia. Warszawa: Wydawnictwo Naukowe PWN; 1997.

8. Weryszko-Chmielewska E, Piotrowska K. Cechy ekologiczne kwiatów most important factors among the analyzed meteorological variables influencing the presence of pollen grains in the atmosphere, while wind and precipitation does not play a significant role.

Humidity and air temperature are related to the release and transport of pollen grains $[42,43]$. Dry and warm weather promotes growth and loosening of pollen grains in anthers, thus the concentration of pollen in the air increases [44]; it decreases when the temperature drops and during rainfalls [45]. The analysis of Spearman's rank correlations revealed that there was a strong statistically significant positive correlation between airborne Betula pollen concentrations and temperature, and a statistically significant negative correlation with humidity and pressure.

\section{Conclusions}

The pollen of allergenic trees in the air of Gudowo was noted between February 11 and May 10, and the highest concentrations were recorded in March and April.

The pollen season of Betula was identified as the compact type, whereas that of Alnus and Corylus as the diffused type.

The highest intensity of the pollen season was recorded in the case of Betula.

The daily pollen concentrations of Alnus, Corylus, and Betula exceeded threshold values, causing allergy symptoms.

The highest alder pollen concentration was recorded at 16:00 and that of hazel at 15:00. The diurnal pattern of birch pollen counts did not show distinctive peaks.

roślin wiatropylnych. In: Weryszko-Chmielewska E, editor. Pyłek roślin w aeroplanktonie różnych regionów Polski. Lublin: Akademia Medyczna; 2006. p. 171-191.

9. Szafer W, Kulczyński S, Pawłowski B. Rośliny polskie I. Warszawa: PWN; 1988.

10. Rapiejko P, Lipiec A. Alergeny pyłku leszczyny. Alergoprofil. 2007;3(2):24-29.

11. Rapiejko P. Alergeny pyłku olszy. Alergoprofil. 2007;3(3):28-33.

12. Weryszko-Chmielewska E, Puc M, Rapiejko P. Comparative analisis of pollen counts of Corylus, Alnus and Betula in Szczecin, Warsaw and Lublin (2000-2001). Ann Agric Environ Med. 2001;8:235-240.

13. Rapiejko P. Alergeny i preparaty alergenowe. In: Kowalski M, editor. Immunoterapia alergenowa. Łódź: Mediton; 2003. p. 48-50.

14. Weryszko-Chmielewska E, Kasprzyk I, Myszkowska D, Piotrowska K, Puc M, Smith M, et al. Aerobiologia. Lublin: Wydawnictwo Akademii Rolniczej w Lublinie; 2007.

15. Rapiejko P. Pyłek roślin jako źródło alergenów. Przegląd Alergologiczny. 2004;1(1):7-12.

16. Galán C, Cariñanos P, Alcázar P, Dominguez-Vilches E. Spanish Aerobiology Network (REA) management and quality manual. Córdoba: Servicio de Publicaciones, Universidad de Córdoba; 2007.

17. Emberlin J, Savage M, Woodman R. Annual variations in the concentrations of Betula pollen in the London area 1961-1990. Grana. 1993;32:359-363. http://dx.doi.org/10.1080/00173139309428965

18. Comtois P. Statistical analysis of aerobiological data. In: Mandrioli P, Comtois P, Levizzani V, editors. Methods in aerobiology. Bologna: Pitagora Editrice Bologna; 1998. p. 217-259.

19. Latałowa M, Miętus M, Uruska A. Seasonal variations in the 
atmospheric Betula pollen count in Gdansk (Southern Baltic coast) in relation to meteorological parameters. Aerobiologia. 2002;18:33-43. http://dx.doi.org/10.1023/A:1014905611834

20. Nowosad J, Stach A, Kasprzyk I, Grewling Ł, Latałowa M, Puc M, et al. Temporal and spatiotemporal autocorrelation of daily concentrations of Alnus, Betula, and Corylus pollen in Poland. Aerobiologia. 2015;31:159-177. http://dx.doi.org/10.1007/s10453-014-9354-2

21. Spieksma FTM. Regional European pollen calendars. In: D’Amato G, Spieksma FTM, Bonini S, editors. Allergenic pollen and pollinosis in Europe. Oxford: Blackwell Scientific; 1991. p. 49-65.

22. Myszkowska D, Bilo B, Stępalska D, Wołek J. Znaczenie monitoringu stacjonarnego i indywidualnego $\mathrm{w}$ diagnostyce alergii pyłkowej. Acta Agrobot. 2006;59(1):373-383. http://dx.doi.org/10.5586/aa.2006.039

23. Rapiejko P, Lipiec A. Stężenie pyłku drzew w atmosferze Warszawy w 1996 roku. Monitor Pyłkowy. 1996;1:2-12.

24. Rapiejko P. Wykorzystanie monitoringu zawartości pyłku roślin w atmosferze w medycynie. In: Book of abstracts: I Ogólnopolska konferencja naukowa „Biologia kwitnienia, nektarowania i zapylania roślin”; 1997 Nov 13-14; Lublin, Poland. Lublin: Wydawnictwo LTN; 1997.

25. Modrzyński M, Weryszko-Chmielewska E, Lipiec A, Malkiewicz M, Myszkowska D, Puc M, et al. Analiza stężenia pyłku olszy w wybranych miastach Polski w 2005 r. Alergoprofil. 2005;1(1):48-53.

26. Puc M, Weryszko-Chmielewska E, Piotrowska K, Grinn-Gofroń A, Myszkowska D, Rapiejko P, et al. Stężenie pyłku olszy w powietrzu wybranych miast Polski w 2006 r. Alergoprofil. 2006;2(2):37-42.

27. Puc M, Kasprzyk I. The patterns of Corylus and Alnus pollen seasons and pollination periods in two Polish cities located in different climatic regions. Aerobiologia. 2013;29:495-511. http://dx.doi.org/10.1007/ s10453-013-9299-x

28. Rapiejko P, Samoliński B, Zielnik-Jurkiewicz B, Lipiec A. Naturalna ekspozycja na bardzo wysokie stężenie pyłku olchy. Alergologia Współczesna. 2001;2(07):26-28.

29. Rapiejko P, Puc M, Lipiec A, Myszkowska D, Piotrowska K, WeryszkoChmielewska E, et al. Analiza stężenia pyłku brzozy w wybranych miastach Polski w 2005 r. Alergoprofil. 2005;1(1):54-58.

30. Myszkowska D. Prediction of the birch pollen season characteristics in Cracow, Poland using an 18-year data series. Aerobiologia. 2013;29:31-44. http://dx.doi.org/10.1007/s10453-012-9260-4

31. Lipiec A, Rapiejko P. Analiza stężenia pyłku brzozy w Warszawie w 2010 r. Alergoprofil. 2010;6(3):22-23.

32. Grewling $€$, Jackowiak B, Nowak M, Uruska A, Smith M. Variations and trends of birch pollen seasons during 15 years (1996-2010) in relation to weather conditions in Poznan (western Poland). Grana. 2012;51:280-292. http://dx.doi.org/10.1080/00173134.2012.700727

33. Myszkowska D, Jenner B, Puc M, Stach A, Nowak M, Malkiewicz $\mathrm{M}$, et al. Spatial variations in the dynamics of the Alnus and Corylus pollen seasons in Poland. Aerobiologia. 2010;26(3):209-221. http:// dx.doi.org/10.1007/s10453-010-9157-z

34. Malkiewicz M, Weryszko-Chmielewska E, Myszkowska D, Piotrkowska K, Tarasewicz A, Lipiec A, et al. Analiza stężenia pyłku leszczyny w wybranych miastach Polski w 2006 r. Alergoprofil. 2006;2(2):31-36.

35. Hyde HA. Tree pollen in Great Britain. Acta Allergol. 1956;10:224-245. http://dx.doi.org/10.1111/j.1398-9995.1956.tb03000.x

36. Kasprzyk I. Palynilogical analysis of airborne pollen fall in Ostrowiec Świętokrzyski in 1995. Ann Agric Environ Med. 1996;3:83-86.
37. Puc M. Pyłek wybranych taksonów roślin w powietrzu Szczecina, 2001-2005. In: Weryszko-Chmielewska E, editor. Pyłek roślin w aeroplanktonie różnych regionów Polski. Lublin: Wyd. Katedra i Zakład farmakognozji z Pracownią Roślin Lych Wydziału Farmaceutycznego Akademii medycznej im. Prof. F. Skubiszewskiego; 2006. p. 49-58.

38. Szczepanek K. Pollen fall in Kraków 1982-1991. Zesz Nauk UJ. 1994;97:9-22.

39. Tarkowski C. Biologia żyta. Warszawa: PWN; 1983.

40. Kasprzyk I. Diurnal concentrations of airborne pollen on Rabka (southern Poland) in 1991. In: Proceedings of the Second Symposium on Pollens and Pollinosis "Pollens and pollinosis: current problems"; 1995 Dec 1-2; Lublin, Poland. Lublin: Institute of Agricultural Medicine; 1995.

41. Grewling $Ł$, Jenerowicz D, Nowak M, Polańska A, Jackowiak B, Czarnecka-Operacz M, et al. Clinical relevance of Corylus pollen in Poznań, western Poland. Ann Agric Environ Med. 2014;21(1):64-69.

42. Palacios I, Molina R, Rodriguez A. The importance of interactions between meteorogical conditions when interpreting their effect on the dispersal of pollen from homogeneously distributed sources. Aerobiologia. 2007;23:17-26. http://dx.doi.org/10.1007/s10453-006-9041-z

43. Piotrowska K, Weryszko-Chmielewska E. Pollen count of selected taxa in the atmosphere of Lublin using two monitoring methods. Ann Agric Environ Med. 2003;10:79-85.

44. Bartková-Ščevková J. The influence of temperaturę, relative humidity and rainfall on the occurrence of pollen allergens (Betula, Poaceae, Ambrosia artemisiifolia) in the atmosphere of Bratislava (Slovakia). Int J Biometeorol. 2003;48:1-5. http://dx.doi.org/10.1007/ s00484-003-0166-2

45. Peternel R, Srnec L, Culig J, Zaninovic K, Mitic B, Vukusic I. Atmospheric pollen season in Zagreb (Croatia) and its relationship with temperature and precipitation. Int J Biometeorol. 2004;48:186-191. http://dx.doi.org/10.1007/s00484-004-0202-x

\section{Zagrożenie alergenami pyłku drzew u chorych z zespołem alergii pyłkowej w środowisku wiejskim Pomorza Zachodniego (Polska).}

\section{Streszczenie}

Celem pracy było przedstawienie koncentracji pyłku Alnus L., Corylus L. i Betula L. we wsi Gudowo (Pomorze Zachodnie, Polska) w latach 2012-2014 oraz ocena zagrożenia alergenami pyłku drzew w rejonach wiejskich. Badania prowadzono metodą wolumetryczną z wykorzystaniem aparatu typu VPPS Lanzoni 2000. Długość trwania sezonu pyłkowego określano na podstawie metody $98 \%$, przyjmując za początek sezonu pojawienie się $1 \%$ całkowitej rocznej sumy stężeń pyłku, a koniec sezonu definiowano, gdy pojawiło się $99 \%$ całkowitej sumy rocznej pyłku. Pyłek leszczyny pojawiał się w aeroplanktonie Pomorza Zachodniego jako pierwszy, przed wystapieniem pyłku olszy i brzozy. Najwcześniej pyłek leszczyny zaobserwowano w roku 2012, natomiast przyspieszenie sezonów pyłkowych olszy i brzozy zanotowano w roku 2014. Najwyższą dzienną koncentrację pyłku badanych gatunków zanotowano w roku 2014. Alergeny występujące w pyłku brzozy stanowią największe zagrożenie dla osób z zespołem alergii pyłkowej. W latach 2012-2014 koncentracja pyłku równa lub wyższa niż wartości progowe, przy których u osób uczulonych wystepuje nasilenie objawów alergii, trwała 25 dni (brzoza), 19 dni (leszczyna), 14 dni (olsza). Najwyższą koncentrację pyłku olszy notowano o 16:00, a pyłku leszczyny o 15:00. Dzienna koncentracja pyłku brzozy nie wykazywała wyraźnych kulminacji. 